\title{
Specifics of Use of Hearsay Testimony as Evidence under Ukrainian and Foreign Criminal Procedure Laws
}

\author{
Alisa Panova \\ Yaroslav Mudryi National Law University, Ukraine \\ alice.panova.1991@gmail.com
}

\begin{abstract}
This article analyses admissibility of hearsay testimony as evidence under the criminal procedure laws of Ukraine. It particularly focuses on statutory safeguards for hearsay testimony used as evidence, and guarantees of human rights and freedoms at the time of the use of any such evidence. The article leads to the conclusion that under applicable criminal procedure laws of Ukraine, the hearsay testimony practices represent one of the reasons for finding factual evidence not admissible for purposes of proof that may be "suppressed" by consenting parties to criminal procedures in the context of their use as evidence per se. Within the article, comparative legal studies of the hearsay testimony practices have also been conducted.
\end{abstract}

Keywords: admissibility of evidence, evidence, finding the evidence inadmissible, hearsay testimony, human rights, proof.

\section{Introduction}

Article 97 of the effective Criminal Procedure Code of Ukraine (hereinafter "the CPC of Ukraine") is the first legal instrument to collate in a single article of the national criminal law a body of rules regulating the admissibility of hearsay testimony as evidence in the course of criminal proceedings and comprising the code of the hearsay testimony.

Pursuant to Part 1 Article 97 of the CPC of Ukraine, hearsay testimony means any statement made in oral, written or any other form, about any specific fact that is based on explanation provided by an individual. 
Under the general rule, such evidence is admissible as proof (providing, however, that it is consistent with applicable laws), and Part 6 Article 97 of the CPC of Ukraine outlines the cases when hearsay testimony cannot be treated as evidence, i.e. regarded as inadmissible. In addition, hearsay testimony is inadmissible if it is inconsistent with a number of statutory requirements.

Hearsay testimony, within the meaning of Part 1 Article 97 of the CPC of Ukraine, implies a statement made by any one individual and retold by a witness, and submitted by a party to the trial (or used by the court) as a proof of what the individual in question is purported to have said [7, 255].

Singularity of the abovementioned concept is based on the assumption that the use of hearsay testimony constitutes an exception from the common rule. This article specifically refers to provisions set forth in Part 4 and Part 5 Article 95 of the CPC of Ukraine, under which the court may base its conclusions solely on testimony it has accepted at the time of the trial or acquired in accordance with procedures outlined in Article 225 of the same Code. The court may not base its resolutions on or refer to the testimony given to the investigator and/or prosecutor. An individual gives testimony referring only to the facts it has perceived personally, unless otherwise specifically provided for by the Code contemplated herein. With this in mind, one may insist that hearsay testimony is an exception from the principle of firsthand study of testimony, material evidence and documents (Article 23 of the CPC of Ukraine).

As O. G. Shylo points out, the use of the latter as evidence in criminal proceedings represents an exception from the common rule that required personal perception of the facts by the individual who gives testimony, as there may be misrepresentation of the obtained information, uncertainty regarding the accuracy of any such information, and the risk of impact of a judgmental factor that compromises the strength of evidence thus provided.

The article aims to get an insight into the essence of hearsay testimony practices in the context of the CPC of Ukraine, and specific ways in which the said testimony may be used as evidence.

This study involved application of comparative method.

\section{Discussion}

Essentially, hearsay testimony represents derivative evidence, and, therefore, the proof shall refer to the primary source of information pertinent to criminal proceedings, and minimise the number of individuals who interpret it. However, by way of exception, the court may find hearsay testimony admissible regardless of whether or not the original person may be brought to testify in the court, if any such testimony represents admissible evidence under other rules regulating admissibility of evidence. 
This is exactly why lawmakers established a number of rules that would limit the use of any such evidence and regulate the admissibility thereof:

1) only the court may rule that such evidence if admissible;

2) only the court may find the evidence admissible if the parties agree that hearsay testimony is evidence;

3) the court may find hearsay testimony admissible if the suspect / defendant created or caused circumstances where the relevant individual cannot be interrogated;

4) hearsay testimony cannot be treated as admissible evidence of the fact or circumstances in proof of which it has been made if the said testimony cannot be backed up by any other evidence that is found admissible under the effective CPC of Ukraine;

5) hearsay testimony can never be treated as admissible evidence, if it is made by the investigator, prosecutor and / or field operative at the time of their involvement in criminal prosecution.

The court may rule that conclusion or opinion of the individual who gives testimony is admissible evidence only if any such conclusion or opinion appears to facilitate clearer understanding of any such testimony (or part thereof) and based on expertise in the sense of Article 101 of the CPC of Ukraine (scientific, engineering, etc.).

If the testifying individual expresses an opinion or conclusion that is based on any such expertise and the court finds them inadmissible in accordance with procedures set forth in Part 2 Article 89 of the CPC of Ukraine, the counterparty may interrogate the said individual in accordance with expert interrogation procedures $[10,152]$.

According to O. Y. Pereverza, the exceptional nature of finding the hearsay testimony is defined by the internal conviction of the court $[8,229]$. Therefore, it is important for literature to provide a tentative list of cases:

1) whenever significance of any such evidence gives the court additional and the only chance to establish the substantial grounds for criminal proceedings, as well as whenever one is unable to prove the sufficient grounds for any such proceedings without any such evidence;

2) the use of any such evidence is justified in the absence or ambiguity of firsthand evidence;

3) the firsthand evidence is lost or cannot be obtained;

4) the hearsay testimony facilitates the search for other evidence that should be factored in while checking the facts that are important for criminal proceedings;

5) details derived from hearsay testimony may serve as a tool for verification of other evidence supplied in the course of criminal proceedings;

6) the hearsay testimony may be used in lieu of firsthand evidence [6, 291-292].

According to D. V. Davydova, the exceptional nature of finding the hearsay testimony is defined exclusively by inability to obtain firsthand information that is vital for criminal proceedings. The author points out that firsthand information may come 
not only from individuals but from documents as well. The research worker further maintains that 266 officers of investigation departments (91\% of the polled individuals) seconded this opinion. With this in mind, the author suggests that hearsay testimony should mean the information provided by a witness in oral, written or any other form about the circumstances that are vital for criminal procedure based on the data obtained from documents or from other individuals if no such information can be obtained firsthand [3, 4]. This point of view refers to practices employed by countries exercising the English-American legal system where hearsay testimony had been recognised as admissible much earlier.

As it follows from literal construction of Article 97 of the CPC of Ukraine, the lawmakers made provisions for a known source of firsthand information, i.e. the individual who has given firsthand testimony. In other words, it is not about information coming from an unknown source. Therefore, hearsay testimony is essentially hearsay. It is rather words retold by another individual. According to Part 2 Article 97 of the CPC of Ukraine, the court may find hearsay testimony admissible by way of exception regardless of whether or not the individual who has given explanations firsthand if the said testimony comprises admissible evidence as defined by other documents regulating the admissibility of evidence. However, Part 4 Article 97 of the CPC of Ukraine allows the court to accept hearsay testimony as admissible evidence if the parties agree and accept the said testimony as evidence.

Scientists reasonably argue that CPC of Ukraine does not oblige the courts to accept hearsay testimony as admissible evidence but rather grants them authority which can be exercised even if and when the parties agree to make hearsay testimony admissible. Considering the criteria set forth in Part 5 Article 97 of the CPC of Ukraine, particularly the right of the court to accept hearsay testimony as evidence if the suspect / defendant created or caused the circumstances where the relevant individual cannot be interrogated, the court may find any such testimony inadmissible even when the parties do not object against admissibility thereof $[7,255]$.

According to the construction of Part 4 Article 97 of the CPC of Ukraine, admissibility of hearsay testimony as evidence is strictly contingent on the consent of the parties to the trial, which implies a consensual procedure envisaged by the lawmaker exactly for the purpose of addressing this matter. In the absence of any such consent, the court may not accept hearsay testimony as evidence. Consent of the parties shall mean their recognition of the accuracy of presented facts which, therefore, may be used as evidence. For example, Appellate Court of Odessa Region in its ruling dated 11.06.2015 (Case No. 520/14721/13-k) had the hearsay testimony removed from the reasoning of the court of the first instance on the grounds that the parties never agreed on the hearsay testimony, which, therefore, cannot be admissible. Appellate Court of Vinnytsya Region in its ruling dated 24.09.2015 (Case No. 127/11102/14-k) points out that it finds the appeal filed by the legal counsel reasonable to the extent applicable to the ruling of the court of the first instance regarding the guilt of the defendant based on unreasonable reference to 
the testimony of a witness - mother of the victim who, in fact, never witnessed the events but, nonetheless, testified in the court of the first instance, and her testimony was based on the story provided by her daughter-in-law and a third party. Pursuant to Part 4 Article 97 of the CPC of Ukraine, the court may accept hearsay testimony as evidence if the parties to the trial agree to accept the same testimony as evidence. As one can see from the trial files, the council for defense never gave its consent. Under these circumstances, the appellate court cannot take testimony of the witness into consideration, and, therefore, references to the said testimony should be removed from the ruling as proof of the defendant's guilt in causing the alleged crime.

As a tool designed to promote competitiveness of judicial proceedings, consensual proof is reasonably seen in criminal proceeding practices as a means that to certain extent balances out the rights of the defense and the prosecution and, therefore, can be treated as actually a kind of leverage to the benefit of the defense.

The study of hearsay testimony practices brings out yet another issue that needs to be considered in detail. Article 97 of the CPC of Ukraine does not specifically regulate admissibility of hearsay testimony. However, it does outline a number of conditions when any such testimony may be admissible as evidence, which means failure to comply with any one of such conditions will terminate evidential value of hearsay testimony. Construction of the hearsay testimony practices implies that one needs to keep in mind that this kind of testimony essentially qualifies as "extrajudicial testimony", and, as such, shall be a subject to the general rule that establishes inadmissibility of any testimony made out of court (Article 23 and Part 4 Article 95 of the CPC of Ukraine).

In addition, general rule that makes hearsay testimony inadmissible is closely tied to the right of the council for defense to interrogate individuals who testify against the defendant, as envisaged by Sub-clause d Clause 6 of the CPHR and Sub-clause e Clause 3 Article 14 of the ICCPR, and embodied in Part 3 Article 23 and Clause 5 Part 2 Article 87 of the CPC of Ukraine. In addition to acquisition of information, the witness needs to be interrogated so as to enable the interrogator to verify the accuracy (reliability) of the acquired information, allow the parties to detect errors or lies in the testimony and thereby weaken or destroy the strength thereof. In the event of admissibility of extrajudicial testimony the party concerned will have no such opportunity. Whenever the court ruling is based on hearsay testimony, the outcome will be the same as with the use of extrajudicial testimony (minutes of witness interview, etc.): in either case, the defendant has no chance of having a witness cross-examined for purposes of establishment of reliability of evidence [7,255]. Considering this kind of "vulnerability" of the defendant whose rights are compromised resulting from admissibility of hearsay testimony, foreign lawmakers proceeded by explicitly banning any such testimony; however, listing the exceptions to this rule.

Article 76 of the Criminal Procedure Code of the Republic of Georgia makes provisions for admissibility of the so-called indirect testimony, i.e. a testimony of a witness that is based on information coming from another individual. Indirect testimony is only 
admissible if the witness who takes the stand specifically mentions the identifiable and verifiable source of information. Indirect evidence at the time of the trial de facto comprises the admissible evidence, providing, however, it is backed up by evidence other than indirect [1].

Criminal Procedure Code of the Republic of Moldova makes no provisions for hearsay testimony. However, it makes a caveat about inadmissibility of the actual data obtained from the source which cannot be verified during the trial, including data which the court does not study in accordance with procedures set by applicable laws (Article 94) [2]. Criminal Procedure Code of Latvia has no provision for admissibility of hearsay testimony as evidence.

The U.S. criminal procedural law also points out the conflict between provisions of the hearsay doctrine and the right of the defendant for cross-examination. As far as criminal prosecution is concerned, there is a clear conflict between the Sixth Amendment to the U.S. Constitution under which the accused "shall enjoy the right ... to be confronted with the witnesses against him", i.e. the right for cross-examination, and the hearsay doctrine that makes numerous exceptions to the general ban on the use of any such testimony.

Meanwhile, in Ohio vs. Roberts (1980), the Supreme Court of the U.S. points out that, providing the hearsay is "sound", no right for cross-examination is compromised. Over the years thereafter, the Supreme Court reviewed its ruling in the context of hearsay testimony time and again. Specifically, in Crawford vs. Washington (2004), the Supreme Court acquitted the accused one, claiming the right of the latter for cross-examination had been infringed. In doing so, the Supreme Court launched a brand new approach toward the problem of admissibility of hearsay testimony and securing the right of the accused for cross-examination. Precedent law of the U.S. keeps evolving in this direction through present [11].

In common law, hearsay testimony is a doctrine of fundamental importance for administration of justice.

Despite the fact that historically this procedural practice in common law implied total inadmissibility of hearsay testimony, contemporary English law makes some exceptions allowing the extensive and rather efficient use of hearsay testimony as evidence. Any such use is contingent exclusively on accuracy of such testimony established by the court. The court proceeds for this purpose by applying the cross-examination procedure. It should be noted that common law defines two aspects of the hearsay doctrine: 1) there shall be no "derivative" testimony, i.e. information from unknown sources and information that cannot be verified through cross-examination; and 2) the right of witness to waive testimony in cases envisaged by applicable laws. Most importantly, every exception involving hearsay is optional and can be exercised only by decision of the court where the latter shall take into account specific circumstances of each and every case and, at its own discretion, decide on admissibility of hearsay evidence in each specific event $[12,133]$. 
However, one should also keep in mind that common law makes provisions requiring the party to a trial notify the counterparty about its intent to use hearsay testimony. The said counterparty may object to the use of such evidence by filing a motion for inadmissibility.

Hearsay testimony will be admissible in any event, if:

1) both parties and the court agree to admit it as evidence;

2) the said evidence facilitates the justice (in cases when the judge decides that the accused will be wrongfully convicted if such evidence is not presented);

3 ) in the event of other court rulings based on the exercise of the same exceptions to the hearsay rules;

4) if directly required so by applicable law.

The following provisions are expressly set forth in applicable law: a) an individual who possesses certain information is unable to appear for the trial and take the stand as a witness (CJA 2003 s.116); b) details are set forth in an official document. Importantly enough, the law allows the judges to act at their own discretion while deciding on the admissibility of hearsay testimony, if the judges feel they are acting to the benefit of justice [4]. Examples of exceptions to the hearsay rule: testimony of an individual who died thereafter or became immune from prosecution; certain official documents, classified data, etc. [5]. However, we would point out that criminal procedural laws of Germany expressly forbid admissibility of hearsay testimony as evidence [9].

\section{Conclusions}

One may reasonably conclude that the concept of admissibility of hearsay testimony under the CPC of Ukraine is borrowed from the hearsay doctrine that emerged in common law. However, the Ukrainian lawmakers eschewed prohibiting the hearsay testimony as evidence under the general rule and listing a number of exceptions to this rule, and, on the contrary, allowed the use of hearsay testimony subject to compliance with statutory requirements. Yet another distinctive feature lies in Part 7 Article 97 of the CPC of Ukraine stipulating that under no circumstance will hearsay testimony be admissible as evidence if it is given by the investigator, prosecutor and / or field operative or any other individual with regard to personal explanations provided to the same investigator, prosecutor and / or field operative at the time of their involvement in criminal prosecution. However, admission of guilt by the accused through a third party, including a police official, constitutes one of the exceptions to the hearsay rule and the court may find it admissible evidence of the guilt of the accused one under the U.S. criminal procedural law. 
Alisa Panova. Specifics of Use of Hearsay Testimony as Evidence under

Ukrainian and Foreign Criminal Procedure Laws

\section{Liecības, atsaucoties uz citu cilvēku vārdiem: izmantošanas îpatnības pierādišanā Ukrainas un ārvalstu kriminālprocesos}

\section{Kopsavilkums}

Rakstā tiek analizēts, vai liecības, atsaucoties uz citu cilvēku vārdiem, ir pielaujamas pierādī̌̌anā atbilstoši Ukrainas Kriminālprocesa kodeksam. Rakstā apskatîtas procesuāāā garantijas, kas paredzētas šādu liecỉbu izmantošanas gadỉjumos. Tiek secināts, ka atbilstoši Ukrainas kriminālprocesa tiesību normām liecības, atsaucoties uz citu cilvēku vārdiem, var tikt atzìtas par nepiẹ̦aujamām, izṇemot gadỉjumus, ja kriminālprocesā iesaistītās puses piekrīt šì pierādījuma izmantošanai. Rakstā aplūkots arī salīdzinošais pētījums par "dzirdes” liecību izmantošanas praksi.

Atslēgvārdi: pierādījumu piel̦aujamība, pierādījumi, pierādījumu atzīšana par nepiel̦aujamiem, "dzirdes" liecības, cilvēktiesības, pierādīšana.

\section{References}

1. Criminal Procedure Code of the Republic of Georgia. 09.10.2009. No. 1772-IIc.

2. Criminal Procedure Code of the Republic of Moldova. 14.03.2003. No. 122-XV.

3. Davydova, D. V. Dzherela dokaziv u kryminalnomu protsesi Ukrayiny: avtoref. dys. 12.00.09. Donetsk Institute of Law with the MIA of Ukraine. Kryvyy Rih, 2015.

4. Hearsay in Criminal Trials. Available from http://www.inbrief.co.uk/court-proceedings/hearsayevidence-in-criminal-cases.htm [date of request: 05.05.2017].

5. "Hearsay" Evidence. Available from http://criminal.findlaw.com/criminal-procedure/hearsayevidence.html [date of request: 05.05.2017].

6. Kryminalnyy protsesualnyy kodeks Ukraiyiny: nauk.-prakt. koment (Eng. The Criminal Procedure Code of Ukraine: scientific-practical commentary). Red.: V. Y. Tatsiy, V. P. Pshonka. Vol. 1.

7. Naukovo-praktychny komentar do kryminalnogo procesualnogo kodeksu Ukraiyiny vid 13 kvitnya 2012 roku (Eng. Scientific-practical commentary of the Criminal Procedure Code of Ukraine of April 13, 2012). Red.: O. A. Banchuk, R. O. Kuybidi, M. I. Havronuka. Factor. 2013.

8. Pereverza, O. Y. Osoblyvosti protsesualnoyi reglamentatsiyi mekhanizmu formuvan pokazan z chuzhykh sliv I taktyky dopytu svidkiv ta poterpilykh, yaki dayut taki pokazannya (za CPC 2012 roku) (Eng. Particularities of procedural regulation mechanism of strangers and tactics of testimony of those who are sick, yaki give the same image (for CPC 2012)). Yurydychnyy naukovyy elektronnyy zhurnal (Legal science electronic journal). 2015. No. 2. p. 228-231. Available from http://lsej.org.ua/2_2015/63.pdf [date of request: 05.05.2017].

9. Schroeder F.-K., Ferrel T. Criminal Procedure Law of Germany.

10. Shylo, O. G. Zahalna harakterystyka pokazan yak protsesualnogo dzherela dokaziv u kryminalnomu provadzhenni. Visnyk kryminalnogo sudochynstva. 1, 2015, 152-153.

11. Taylor, David H. Hearsay and the Right of Confrontation in American Trials by Jury. Available from http://commons.lib.niu.edu/handle/10843/16458 [date of request: 05.05.2017]. 
Alisa Panova. Specifics of Use of Hearsay Testimony as Evidence under Ukrainian and Foreign Criminal Procedure Laws

12. Teryokhin, V. V. O probleme dopustimosti "svidetelstv po slukhu" v ugolovnom protsesse (Eng. On the problem of the admissibility of "evidence on hearing" in the criminal process). Uchyonye zapiski I materialy kruglogo stola, posvyashchyonnogo pamyati doktora prava, ordinarnogo professora Malysheva K. I., (1841-1907): sb. st. prepodavateley, magistrov i aspirantov (Eng. Scientific notes and materials of the round table devoted to the memory of the doctor of law, Professor Malysheva K. I., (1841-1907)):. Chelyabinsk, 2013. 